\title{
Where the Prophet's Wife Rode a Camel: a Review of the Feminist Perspectives and Orientations Rooted in Islam
}

\author{
Sabrina Iqbal Sircar \\ Faculty, Department of Political Science Cotton College State University, Guwahati
}

\section{TEXT}

The ethical project of Islamic feminism shares the central ideals and values of Islam itself —of justice, egalitarianism, equity, compassion, and tolerance. By opening up the question of who has the authority to interpret scripture, and by challenging the power of traditional interpretive communities and the producers of religious knowledge, Islamic feminists are at the forefront of the contemporary reformist movement. Writers such as Amina Wadud and Asma Barlas are conferring upon themselves the authority to challenge the monopoly of traditional interpreters of the Quran, whilst scholars such as Fatima Mernissi are engaged in contesting received notions of Hadith literature. All such scholars are engaged in revisiting Islamic sources and actively furthering what has been succinctly termed the "democratization of ijtihad. ${ }^{1}$ Working within Islamic jurisprudence, this entails the use of an interpretive methodology, ijtihad (to strive or) to dynamically reinterpret foundational Quranic principles in order to bring about equal rights for women. ${ }^{2}$

Feminism and Islam or Islamic feminism still remains a subject of confusion and contention for many because they still regard the term as an oxymoron. For them the two, feminism and Islam cannot be related or even juxtaposed with one another as they are completely bi-polar concepts. This is true for the Muslim communities and the West as well. But a splurge in Islamic feminist literature has forced people to think otherwise as Muslim intellectuals though mostly women are now challenging traditional understandings popularised through the medium of religion and legalised in the name of Prophetic Tradition. Islamic feminists are reinterpreting Islamic sources in order to achieve equal rights for women within an Islamic framework. They have challenged traditional interpretations of the scriptures and received notions of interpretive authority, both in Muslim majority societies as well as in the diasporic Islamic world. With their new interpretations they have contributed to the transformation of the legal, political and social rights of Muslim women. There are, however, also limitations to the feminist interpretations of scripture and their potential to deliver gender equality. ${ }^{3}$

What is actually noteworthy in this context is that the feminists advocating gender egalitarianism have not gone beyond the framework of Islam nor are these feminisms derivative (of the West) ; rather these are inspired by religious scriptures, mainly the Qu'ran and other similar sources. The scholastic discourse on Islamic feminism has come up with two distinct schools of the feminism prevalent in Islamist circles - Secular feminism and Islamic feminism; but both of these are inspired and structured explicitly and implicitly within the boundaries of the religion. To elaborate this in a simpler parlance would mean that feminist orientations and perspectives have always been integral to the religion, but it has precisely been the Muslim male elite which has time and again manipulated the basics and teachings of the religion and the Prophet (PBUH) thus constructing Islam as a misogynist and more of an androcentric religion.

This paper will thus try to break the clichés associated with women and Islam; and will attempt to elaborate how the Islamic feminists have been inspired to formulate a school of their own, intended specifically to protect the rights of Muslim women.

In the beginning it needs to be understood that Islam, as a religion grants a much privileged position to the woman and does not treat her as the subjugated sex, left at the mercy of her male counterpart. The religion from the time of its inception itself had considered women at par with the men, mentioning women along with the men, in the holy scriptures and verses. Though there are slight altercations in the interpretation of these, but in no way does the religion tend to accord a second sex status to the Muslim womenfolk. The Muslim women however became the scapegoat when the male elite of the religion took in their hands the task of interpreting and asserting the teachings of the same. The reality was manipulated and statements meant to preserve the status quo of predominantly Muslim societies, so that the balance of power does not upset in the favour of the Muslim women.

\footnotetext{
${ }^{1}$ Mirza Qudsia, Islamic Feminism and Gender Equality, ISIM Review 21/ Spring 2008

https://openaccess.leidenuniv.nl/bitstream/handle/1887/17220/ISIM_21_Islamic_Feminism_and_Gender_Equality.pdf?sequence=1, Retrieved 18the November 2013

${ }^{2}$ Ibid

${ }^{3} \mathrm{Ibid}$

DOI: $10.9790 / 0837-2104024649$

www.iosrjournals.org $46 \mid$ Page
} 
This is where the feminists come in, they look to the time of the origin of Islam and assert that women, who had played a significant role as the creators of oral texts, became invisible after the inception of Islam, both as originators and interpreters of such texts. Scriptural literature was then produced by men who incorporated their own restrictive assumptions and understanding of gender relations. Legal texts were also created in this way and a masculine bent was inscribed into the legal literature of that time, resulting in the atrophying of the egalitarian ethos of Islam. Thus, the feminist project is based squarely upon an Islamic framework within which an ethically correct gender paradigm and resulting legal rights for women may be configured. ${ }^{4}$

In fact as has been highlighted by many, Islam does not discriminate or even focus on the difference between the sexes. Male and female have always been mentioned together and have been treated the same as per the principles and teachings of the Qu'ran. The Islam of Mohammed (PBUH) claims to treat women and men equally, particularly in the spiritual realm. The Quran does not restrict the blessings and rewards of God to men alone. On the contrary, it aims to establish a society in which social and spiritual justice should flourish without the segregation of sexes. But Islam's concept of justice does not mean that all human beings are equal in terms of natural capabilities and human efforts to transform those skills into creativity and constructivism. As, He says "Indeed the literate has an edge over an illiterate and not the vice versa", on other hand the Quranic criterion of justice does not depend upon gender but rather it is rooted in the principle of "taqwa" - righteousness. God proclaims the spiritual equality of all the true believers in such strong words: "Lo! Men who surrender unto Allah, and women who surrender, and men who believe and women who believe, and men who obey and women who obey, and men who speak the truth and women who speak the truth, and men who preserve (in righteousness) and women who preserve, and men who are humble and women who are humble, and men who give alms and women who give alms, and men who fast and women who fast, and men who safeguard (their modesty) and women who guard (their modesty), and men who remember Allah much and women who remember-Allah hath prepared for them forgiveness and a vast reward." 5

In fact the situation in the present day Muslim countries like Saudi Arabia and some others is a total irony of the situation during the times of the Prophet (PBUH). It is not a very popular fact but the Prophet of Islam was one of the first feminists who had done a considerable lot to improve and enhance the plight of the womenfolk of his times. He had advocated female education, widow remarriage and the right to work as well, all as rights of women under Islam. But contradictory to this, in the contemporary times, the women in most Muslim countries have to fight for their basic rights and have to follow dress codes imposed on them by the socalled Islamic governments etc. I had read article where, in such a country, a girls school which had caught fire was burnt down to ashes as the firemen were not allowed to rescue the girls as they were "not properly covered" ; the religious police did not allow the rescue operation. Instances like this are a complete mockery of Islam and its principles.

The Holy Book of the Muslims uses the expression "believing men and believing women" to emphasize the equality of men and women with regard to their responsibilities, duties, rights, virtues towards God. By the very nature and implication of this Ayat, (verse of the Qur'an) both men and women have been declared equal before God, hence before the Islamic law. As a pious man is accountable to God and rewardable from God, a devout and righteous woman is also entitled to Devine blessings and fruits of Paradise. This command of the Quran, by creating a parity of gender, indicates the egalitarian structure of Mohammed's (PBUH) Islam. This verse also demands an equal amount of religious duties from all true believers, regardless of gender. But God of Muslims does not stop here; He rather extends His vision of equity between the two sexes to the realms of wrongdoing and punishment, "As for the thief both male and female, cut off their hands". Again by this verse God has made both male and female equally accountable to the rule of law. ${ }^{6}$

From the above we infer that there is specific and substantial evidence supporting the fact that Islam has a feminist dimension to it, intended to protect the rights and dignity of the Muslim women. The Prophet (PBUH) himself had patronized the women to achieve more, during his times itself. There is also considerable evidence supporting the fact that, before the advent of Islam, that is when paganism was prevalent in Arabia, the women had been reduced to sexual objects, meant merely for the fulfilment of male desires and were treated no more than elements of sexual gratification. With the coming in of Islam, the women were rescued from such a pathetic course and were placed with dignity and respect in society.

Islam has not only placed women highly but has also accorded the right to them to lead societies and there have been evidences of these since the times of the Prophet (PBUH) himself. The political and military leadership of Aisha (RA), who had led the Battle of Camel, the legal battle of Hazrat Fatimah against the first righteous Caliph, the political leadership of Sheikh Hasina nd Benazir Bhutto, in Islamic countries have proven

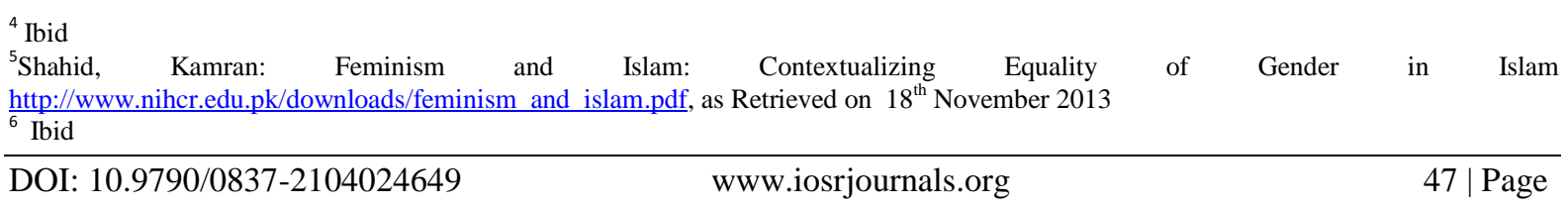


beyond doubt that women are not only capable of leading societies but in fact they have excelled at it. The mention of Aisha (RA), in this regard holds special significance because, the very fact that the she, Aisha (RA), a young wife of the Prophet (PBUH) could lead a battle against the men during her times itself brings out the irony, when compared to the fact that, today, in the same land, women are not allowed to drive and are denied many other rights as well. If Aisha (RA) could ride a camel and lead a battle during that time, today thousands of years later, why are the women in the same land, after so much progress and development of society, not allowed to drive? Isn't this extremely ironic?

Now let us try to analyse where the problem lies. The religion grants rights to the women, the Prophet (PBUH), advocated and supported women's rights, then when and how did this misogynistic image of Islam come into being? There are basically two primary reasons for this --- Firstly many things in Islam were situational, which again came with specific conditions, but later on they were conveniently interpreted as generally acceptable, which thus developed the scope for criticism. One such example would be the practice of polygamy. Polygamy was permitted by the religion at a time when war was rampant and women were widowed in large numbers; in addition to this the sex ratio had been upset and a large number of women were left as spinsters. Now, a single woman, whether unmarried or widowed as always viewed as vulnerable, someone who could be easily accessed by the men of the society. Thus, to protect the dignity of the womenfolk and to ensure that all the women had a husband who would be her partner and protector (during those times, a male member was entrusted the protection of a woman's dignity), the provision of polygamy was established. However, polygamy also came with a lot of rules, which, if the men could not follow, they could not marry more than one wife. But all these rules and the situational significance of polygamy was overlooked by the male masses later on, who just interpreted and accepted polygamy as a provision which would allow them more pleasure. In fact polygamy was not allowed in normal situations at all but this fact was not highlighted as the men would be in a disfavoured position, with the opportunity of marrying more than one being taken away from them.

The second reason is the misinterpretation of the religious texts and scriptures. Fatima Mernissi, had stated in her work that Al-Bukhari, who was an intellectual, who had reviewed the Hadiths and had tried to test their veracity had found by implying the scientific method that out of 7,257 Hadiths which were claimed as authentic, 4000 of them were false and had to be eliminated. The main aim of Al-Bukahri as pointed out by Mernissi "was to be true to Mohammad (PBUH) - that is , to avoid having him say something that he had not said." Mernissi also highlights a very important fact that if at the time of Al-Bukhari that is less than two centuries after the Prophet there were more than 500,000 false Hadiths, then in the present day, we can imagine how many of them are there. Al-Bukahri, further went on to write on the life of the transmitters of the Hadith, entitled, Al-tarikh al-kabir, (The Great History) to determine the authenticity of the people who wrote the Hadiths. ${ }^{7}$ Mernissi also states the justification for such wrong records of the Hadiths. When the Prophet (PBUH) of Islam was advocating rights for the Muslim women and preaching for women's equality, the male elite of that time were perturbed, as their privileged position was at threat. What the Prophet (PBUH) was advocating, would bestow equal rights to the women and thus would eliminate the status quo and upset the balance of power which, at that time was in favour of the women. Thus the male elite lobbied and paid the collectors of knowledge that is the writers of the Hadiths to manipulate the sayings of the Prophet (PBUH), which favoured the women and to instead turn them against the women so that they enjoyed their superior position and could continue to dominate over the women. 8

Many interpreters and clerics who claim to have authority as interpreters of the religion have manipulated the reality of the religion. Verses have been completely turned around to justify that the women is not entitled to independence and should be subservient to the man. There is a particular Ayat of the Qur'an which entrusts on the men the responsibility of the woman, and gives the man authority in as far as the family is concerned. According to this Ayat Islam has made man responsible for the needs and comforts of his wife. In other words, Islam has protected the latter from the strains of the hardworking task of earning. In return, Islam demands a woman to show and give her love, loyalty and obedience to her man as a token of gratitude for the efforts her man is doing in order to keep her welfare and prosperity intact. This Ayat does not seem to reduce the status of a woman by subjugating her to the social, cultural, political and intellectual domination of man. On the contrary, it has made man more responsible and demands from him more loyalty and affection towards his woman. Instead of upsetting the balance of equality, it stipulates the balance of rights and responsibilities between husband and wife or man and woman. ${ }^{9}$ Later on Umar-al-Baydawi used this Ayat as a misogynist tool against the women of the religion. He maintained that this Ayat had established the superiority of the men over the women. This is evident when he had said that the men are in-charge of the women as a king is in-charge of

\footnotetext{
${ }^{7}$ Mernissi, Fatima, The Veil and the Male Elite - A Feminist Interpretation of Women's Rights in Islam, (1987. 1991) Library of Congress Cataloguing-in-Publication Data, , pg 44-45

${ }^{8}$ Ibid 45

${ }^{9}$ Shahid Kamran Feminism and Islam: Contextualizing Equality of Gender in Islam http://www.nihcr.edu.pk/downloads/feminism_and_islam.pdf, Retrieved $18^{\text {th }}$ November 2013
}

DOI: $10.9790 / 0837-2104024649 \quad$ www.iosrjournals.org 48 | Page 
his subjects. Such a $\mathrm{n}$ interpretation turned the tables completely and absolutely in the favour of the men, thus establishing the women as the second sex, one that can do nothing without assistance and permission from the male. It is exactly such misinterpretation which leads to complete manipulation of the religious texts. ${ }^{10}$

The feminists perspectives of the religion have always been stage-managed for the Muslim society, primarily dominated for the men, and of course by the men, specifically the Muslim male elite who claim to be the pseudo protectors of the religion. The imams and clerics who issue fatwas at the slightest things of the Muslim women, however do not seem even to budge when the men do things completely against the spirit of the Prophet's Islam. It is these things which have compelled the Muslim women to speak up for the cause of themselves as well as for the sake of the religion. Throughout the Muslim world, a groundswell of feminist sentiment is growing among women who are seeking to reclaim Islam and the Qur'an for themselves. For decades, many women believed they had to choose between their Muslim identity and their belief in gender equality. It was an impossible choice-one that involved betraying either their faith or their feminist consciousness. ${ }^{11}$

In the recent past the Muslim women have realised that it is not Islam which suppresses or restricts their freedom, but rather the Muslims who do so. Amina Wadud in her work the The Gender Jihad, (2006), had very aptly stated that there is a difference between what Islam, teaches and what Muslims do. And this exactly what has been the case in this context. Islam as a religion is egalitarian, but the people practicing it, have manoeuvred the religion as and how it is convenient for them to construct an androcentric and anti-feminist Islam, one that treats women as secondary to the men. The spread of Islam to societies which were patriarchal from the start, led to the emergence of a gender-biased Islam to suit the needs of such a society. The misinterpretation by some writers led to the development of a specific variety of Islam, one which does not treat women as an equal, denies her the right to education, the right to work outside home, but just restricts her functions to within the four walls of the house and specifies her duties as cooking, reproduction, and pleasing her husband. This variety of Islam, is man-made, which instilled a conception in the minds of the Muslims that the woman is to be treated the way the men want, and most importantly, established that, as Allah's, the Muslims God's will. Thus legalizing the oppression of women as a religious right!

The insight that a feminism can be developed within the framework of Islam, came with the realisation that Islam does not restrict or hamper women's freedom, instead, encourages the same. Thus a school of feminism, much controversially enough termed as Islamic feminism emerged, which sought to deliver Muslim women their rights very much within the religion. Hence, for once, 'Islamic Feminism', did not seem like an oxymoron, so conveniently and popularly believed to be so. With the Muslim women coming to the forefront to question the divinity and veracity of women oppressing, 'Islamic guidelines', and with Muslim men and women world over forming associations and organisations to protect Muslim women and their rights, Islamic feminism has now come as a challenge to those Muslims who believe women belong in the private and should play second fiddle to the men. Sisters in Islam and Musawah (meaning equality in Arabic) are some such associations which deserve a mention in this regard. Musawah operates as a kind of research institute, commissioning the work of international experts in the fields of Islamic jurisprudence, history and ethics to find counter-narratives that are liberating to women. One of the experts, Muhammad Khalid Masud, a judge on the Shariat appellate bench for the Supreme Court of Pakistan, argues, "The Koran did not invent or introduce patriarchy." He says that Islamic scriptures were written at a time when the dominant culture in the Middle East was patriarchal, and must be read in this context. "The Koran must be historicized before applying it to modern issues,"; Musawah is undertaking an extensive knowledge-building project on the issue of male authority over women in an effort to fight for family-law reforms. ${ }^{12}$ Along with this, with young women, as young as Malala Yusufzai coming to risk death to avail their basic rights has been a great boost to the achievement of the rights of Muslim women.

Islamic feminism basically and essentially tries to establish the fact that Islam as a religion inherently has a feminist edge. It mentions men and women together in the holy book, the Qur'an; does not discriminate on the basis of gender ; and guarantees women the right to property, which is a rarity as no other religion does so (Hinduism incorporated the right to property for the women only by the Succession Act of 1956). Thus what is needed is to review these feminist perspectives of the religion and establish it as gender-sensitive and egalitarian which seeks to treat well and encourage the women in whatever they do. No religion teaches or preaches oppression of women and Islam is no exception to this rule.

\footnotetext{
${ }^{10}$ Ibid

${ }^{11} \mathrm{http}: / /$ www.thenation.com/article/177467/rise-islamic-feminists as Retrieved on $14^{\text {th }}$ January, 2014

12 Ibid
} 